\title{
Post-surgical surveillance in Lynch syndrome-a Cleveland Clinic experience
}

\author{
Susan Fay ${ }^{1 *}$, Ellen McGannon ${ }^{1}$, James M Church $^{2}$ \\ From 14th Annual Meeting of the Collaborative Group of the Americas on Inherited Colorectal Cancer \\ Dallas, TX, USA. 12-13 October 2010
}

\section{Background}

Post-surgical colonoscopic surveillance is recommended every 1-2 years for patients diagnosed with colon cancer and Lynch syndrome. Patients electing to have a segmental versus colectomy IRA risk developing metachronous colon cancers. The rationale for frequent surveillance is to detect and remove polyps before pathologically advancing to cancer thereby reducing mortality. Does compliance with recommended surveillance eliminate the risk of metachronous cancers?

\section{Method}

A database search for MMR+ families enrolled in the Jagelman Inherited Colorectal Cancer Registry was performed. Patients suitable for this study were status post surgery for colon cancer with the surgery and post operative follow-ups being performed at the Cleveland Clinic.

\section{Results}

22 patients in 16 families were identified as meeting criteria described above. All but 2 patients are living. One cause of death was advanced colon cancer; the other non-cancer related. Sixteen (64\%) segmental resections or hemicolectomies were performed in 14 patients, 3 of the 14 patients had a second surgery for metachronous colon cancer. Colectomy IRAs were performed in 9 patients (36\%). Surgeries dated from 1978 to 2010. Collectively, 82 follow-up (FU) colonoscopy, sigmoidoscopy or proctoscopy exams were performed (range 1-9/ patient). The interval between surgery and first FU or subsequent FUs totaled 163 years (range 1-22; mean=6.8; median=5). No polyps or cancers were detected in patients having a colectomy IRA. Polyps were detected in 12 out of the 14 (86\%) patients who had segmental resections. An analysis of polyp and cancer incidence in patients having segmental resection is shown in Table 1. Figure 1 shows the point within and outside the 1-2 year recommended surveillance period pathologically advanced polyps and cancers were detected.

Further analysis indicates that if a polyp is detected in a FU exam, it is $28 \%$ likely to be pathologically advanced and $16 \%$ likely to be cancer.

\section{Conclusion}

1. Compliance with post surgical surveillance guidelines does not eliminate risk of metachronous cancers.

Table 1 Incidence of polyps and cancer following segmental resection

\begin{tabular}{llllll}
\hline $\begin{array}{l}\text { \#FU } \\
\text { Exams }\end{array}$ & $\begin{array}{l}\text { \#FU exams } \\
\text { detected } \\
\text { polyps }\end{array}$ & $\begin{array}{l}\text { \#FU exams detected } \\
\text { pathologically advanced } \\
\text { polyps* }\end{array}$ & $\begin{array}{l}\text { \#FU exams } \\
\text { detected } \\
\text { cancers }\end{array}$ & $\begin{array}{l}\text { Interval between FU \& polyp } \\
\text { detected (range= 0.5-4.5 yrs) }\end{array}$ & $\begin{array}{l}\text { Interval between FU \& cancer } \\
\text { detected (range= 0.5-3 yrs) }\end{array}$ \\
\hline 52 & $25(48 \%)$ & $7(13 \%)$ & $4(8 \%)$ & $\begin{array}{l}\text { Mean=1.5yr } \\
\text { Median=1yr }\end{array}$ & $\begin{array}{l}\text { Mean=1.4yr } \\
\text { Median= 1yr }\end{array}$ \\
\hline
\end{tabular}

*pathologically advanced polyp is described as an adenoma being $1 \mathrm{~cm}$ or larger, having a villous component, or high-grade or severe dysplasia.

\footnotetext{
* Correspondence: fays@ccf.org

${ }^{1}$ Taussig Cancer Institute, Sanford R. Weiss, M.D. Center of Hereditary

Colorectal Neoplasia, Cleveland Clinic, Cleveland, Ohio, USA

Full list of author information is available at the end of the article
} 


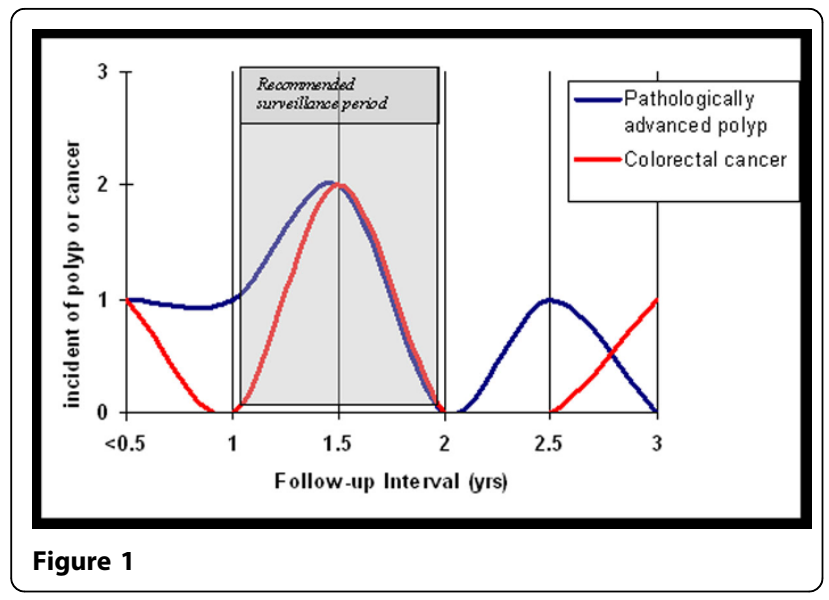

2. Pathologically advanced polyps and cancers can occur within 1 year status post segmental resection.

\section{Author details}

${ }^{1}$ Taussig Cancer Institute, Sanford R. Weiss, M.D. Center of Hereditary Colorectal Neoplasia, Cleveland Clinic, Cleveland, Ohio, USA. ${ }^{2}$ Colorectal Surgery Department, Digestive Disease Institute, Sanford R. Weiss, M.D. Center of Hereditary Colorectal Neoplasia, Cleveland Clinic, Cleveland, Ohio, USA.

Published: 10 March 2011

doi:10.1186/1897-4287-9-S1-P13

Cite this article as: Fay et al:: Post-surgical surveillance in Lynch

syndrome-a Cleveland Clinic experience. Hereditary Cancer in Clinical Practice 2011 9(Suppl 1):P13.
Submit your next manuscript to BioMed Central and take full advantage of:

- Convenient online submission

- Thorough peer review

- No space constraints or color figure charges

- Immediate publication on acceptance

- Inclusion in PubMed, CAS, Scopus and Google Scholar

- Research which is freely available for redistribution

Submit your manuscript at www.biomedcentral.com/submit 